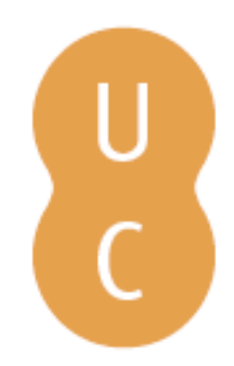

\title{
nombalina
}

Mafalda de Mouriana e Sabóia (1130/1133 - 1158), primeira rainha de Portugal

Autor(es): $\quad$ Marques, Maria Alegria Fernandes

Publicado por: Imprensa da Universidade de Coimbra

URL

persistente:

URI:http://hdl.handle.net/10316.2/32329

DOI:

DOl:http://dx.doi.org/10.14195/978-989-26-0604-0_1

Accessed : $\quad$ 26-Apr-2023 11:45:28

A navegação consulta e descarregamento dos títulos inseridos nas Bibliotecas Digitais UC Digitalis, UC Pombalina e UC Impactum, pressupõem a aceitação plena e sem reservas dos Termos e Condições de Uso destas Bibliotecas Digitais, disponíveis em https://digitalis.uc.pt/pt-pt/termos.

Conforme exposto nos referidos Termos e Condições de Uso, o descarregamento de títulos de acesso restrito requer uma licença válida de autorização devendo o utilizador aceder ao(s) documento(s) a partir de um endereço de IP da instituição detentora da supramencionada licença.

Ao utilizador é apenas permitido o descarregamento para uso pessoal, pelo que o emprego do(s) título(s) descarregado(s) para outro fim, designadamente comercial, carece de autorização do respetivo autor ou editor da obra.

Na medida em que todas as obras da UC Digitalis se encontram protegidas pelo Código do Direito de Autor e Direitos Conexos e demais legislação aplicável, toda a cópia, parcial ou total, deste documento, nos casos em que é legalmente admitida, deverá conter ou fazer-se acompanhar por este aviso. 


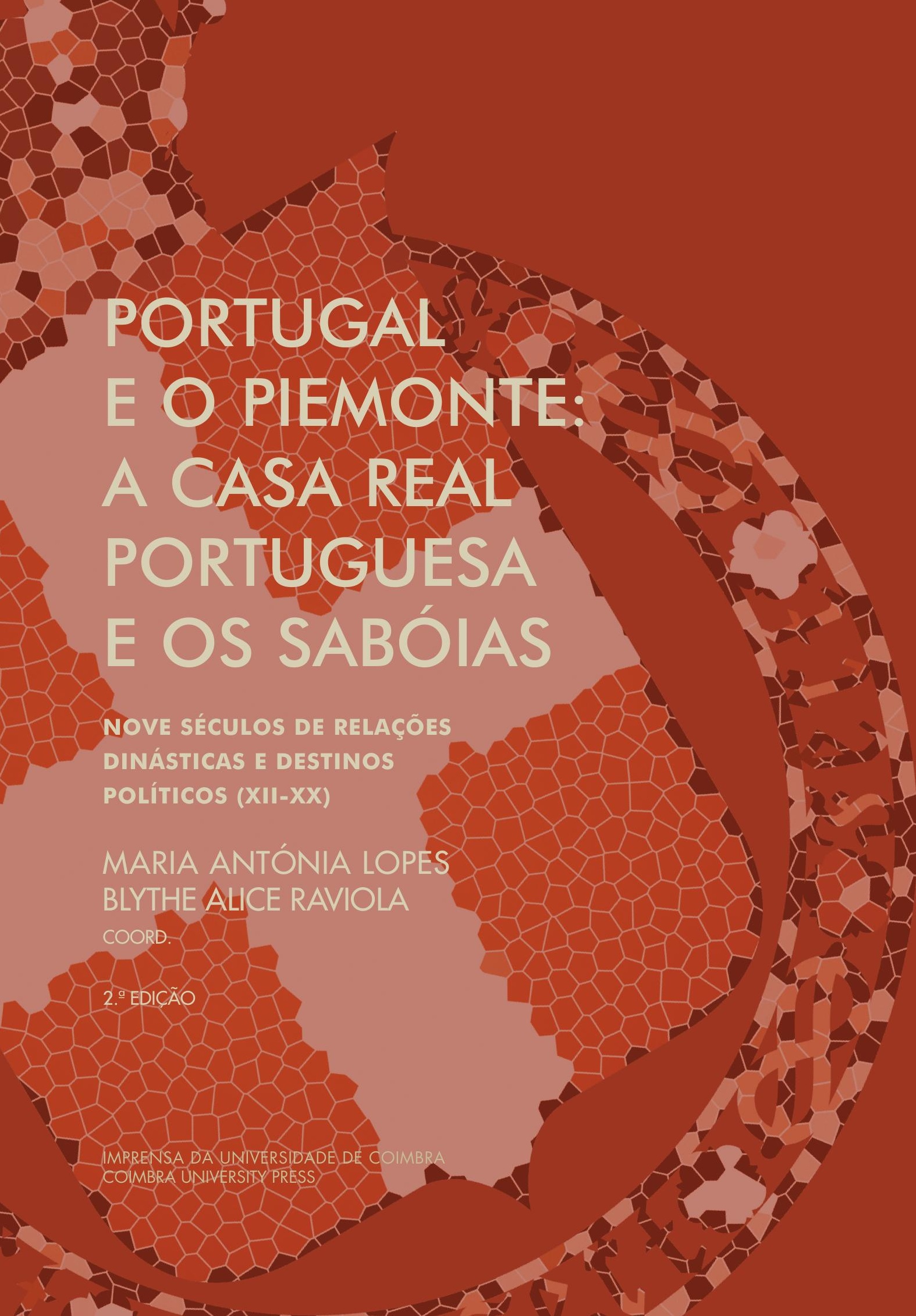


Maria Alegria Fernandes Marques

Universidade de Coimbra

\section{MAFALDA DE MOURIANA E SABÓIA \\ (1130/1133 - 1158), \\ PRIMEIRA RAINHA DE PORTUGAL}

\section{Introdução}

D. Mafalda de Mouriana e Sabóia ganhou um lugar na História de Portugal pelo seu casamento com D. Afonso Henriques, primeiro rei de Portugal. No entanto, a sua figura é apagada e fugidia na documentação portuguesa. Se é certo que a sua vida foi breve e a sua condição de rainha mais fugaz ainda, também é verdade que, pelo tempo em que viveu, as mulheres raramente originavam uma memória própria, confundindo-se e obliterando-se, a sua, com a de seus maridos, quando casadas, numa prova de que elas só assumiam uma presença em função deles.

Mesmo assim, percorrendo velhos pergaminhos, relendo as velhas crónicas e questionando a época, sempre se encontram ou novas leituras ou diferentes pistas para lhe buscar uma razão da sua vinda para Portugal e encontrar algum desígnio no seu papel de rainha. Que rei e que reino encontrou Mafalda à sua chegada a Portugal? Como entender o seu casamento, desde a sua escolha para rainha de Portugal, até aos problemas da intermediação e da sua realização? Que se sabe acerca do protagonismo da rainha Mafalda de Mouriana e Sabóia em Portugal? Qual foi a sua descendência? São as questões a que procuraremos dar resposta, apesar da exiguidade e parcimónia das fontes no que à sua figura diz respeito. 


\section{Um reino em busca de rainha}

O casamento de D. Afonso Henriques com D. Mafalda de Mouriana e Sabóia deve ter tido lugar em 1145, como veremos.

Por esse tempo, já Afonso Henriques contava com uma longa década à frente dos destinos da terra portuguesa. Começava a ficar longe, no tempo, o dia 28 de Junho de 1128, no qual, no campo de S. Mamede, próximo de Guimarães, vencera os indignos estrangeiros (como lhes chamaram as memórias acerca do seu tempo, apologéticas do rei de Portugal e vinculadas à lembrança que dele guardou o mosteiro de Santa Cruz de Coimbra ${ }^{1}$ ) que rodeavam sua mãe e influenciavam a sua governação. Desde então, Afonso Henriques percorrera um longo caminho de afirmação interna e externa, perante uma nobreza a que teria de se impor e as forças estrangeiras a que era necessário dar sinais claros da sua determinação e da sua capacidade política, governativa e militar. Como corolário, Afonso Henriques tinha alcançado o reconhecimento dos seus fiéis e a legitimação do seu poder, com a sua aclamação como rei, em Ourique, nas vésperas da batalha aí travada e que havia de tornar-se num dos mitos maiores da História de Portugal, bem como havia ganho um lugar entre os governantes da Cristandade. Ao mesmo tempo, era já um guerreiro experimentado e respeitado pelos muçulmanos peninsulares. A memória da batalha de Ourique seria uma das mais felizes que Mafalda encontrou à sua chegada a Portugal.

Muitas outras memórias e realidades esperavam Mafalda em Portugal. Tomaria conhecimento da importante teia de relações familiares que envolviam o marido, bem como das preocupações políticas do reino onde chegara para reinar. As primeiras levá-la-iam ao conhecimento do reino de Leão e Castela, à memória da mãe de seu marido e do seu governo da Terra Portuguesa, da acção de Afonso Henriques relativamente ao poder na mesma Terra, das relações dele com seu primo, Afonso VII de Leão e Castela. Perceberia, assim, que aqui também, como na terra de onde provinha, tais relações eram facilmente relegadas pelos interesses da política e, se esta o exigia, ultrapassadas por soluções extremas, de carácter militar. Isso mesmo

\footnotetext{
1 BLÖCKER-WALTER, M., 1966, p. 152.
} 
lhe representaria o que se diria, na corte, acerca dos problemas da fronteira do Norte, com terras da Galiza, e do recontro de Valdevez, em 1141, entre as tropas de seu marido e as do primo, imperador de Leão e Castela.

Nas meias palavras das conversas ou em comentário mais loquaz, facilmente terá percebido, ou confirmado, como o título de rei que adornava o nome de seu marido, não era, afinal, de um consenso absoluto em todas as paragens. Com isso também se ligaria o que era bem presente, na corte, acerca do acto de vassalagem que o rei de Portugal tinha prestado à Santa Sé, nas mãos do legado papal, cardeal Guido de Vico, em Zamora, em 1143, e que complementara por documento, enviado à Santa Sé, em 13 de Dezembro de 1143, conhecido por "Claves regni celorum", do nome do seu incipit ou primeiras palavras. O rei de Portugal pretendia, assim, colocar-se a si, aos seus descendentes e à sua terra, sob a protecção da Santa Sé, em determinadas condições, de que sobressaía a sua constituição voluntária de censitário de São Pedro. Na corte, mais se falaria da resposta do papa Lúcio II, transmitida por bula datada de 1 de Maio de 1144: o pontífice aceitava o que era oferecido à Santa Sé, louvava Afonso Henriques pelas disposições tomadas, garantia-lhe tudo aquilo que ele havia pedido e solicitava persistência no seu amor à Igreja. Mas não lhe confirmava o título régio. Apesar disso, também não houve recuo na prática do rei de Portugal, nem sintoma, mínimo que fosse, de qualquer embaraço entre as partes. Sinal claro de que o rei e o reino de Portugal procuravam afirmar-se na Europa do seu tempo, ao mais alto nível, a Santa Sé, a instância mais poderosa e universal que ela conhecia. Mas isto, também Mafalda o saberia.

Aliás, a sua presença em Portugal era a prova desse desiderato, além de que ela conheceria bem as relações com S. Bernardo, outro bom exemplo da perspicácia política que orientava seu marido e os que o rodeavam. Por essa razão, talvez que de todos os documentos da chancelaria de seu marido em que ela veio a figurar, lhe tenha dado particular alegria aquele que fazia doação e couto de Alcobaça ao abade Bernardo de Claraval, em $1153^{2}$.

Chegada a Portugal, vinda de longes terras, para reinar, que reino oferecia Afonso Henriques, a Mafalda de Mouriana?

\footnotetext{
2 DR 243.
} 
Pouco tempo depois de ter triunfado, em S. Mamede, Afonso Henriques fizera de Coimbra o centro das terras de Portugal. Afastava-se do Norte, terra de poderes senhoriais, para um território mais livre desses poderes e um espaço mais próximo dos muçulmanos. Buscaria uma mais fácil defesa da sua terra, uma maior possibilidade de organização de campanhas guerreiras, em vista do alargamento do território, e talvez também a oportunidade de façanhas heróicas, que lhe dessem a legitimação maior de um chefe, segundo as concepções do tempo.

Coimbra era uma cidade com largos anos de domínio cristão e uma terra de fortes lembranças de seus pais, mormente a conquista do seu foral, em processo que enaltecia o apego à liberdade e à tradição, por parte das gentes coimbrãs. Afonso Henriques saberia honrar essa herança. De imediato, com a doação dos seus banhos, ao arcediago da cidade, Telo, para a fundação de uma canónica, que havia de se afirmar como o grande mosteiro de Santa Cruz. O próprio rei se lhe haveria de afeiçoar a ponto de fazer dele a derradeira morada de seus entes queridos e, mais tarde, a sua própria.

Mulher do seu tempo, Mafalda não ignoraria os problemas que a Europa travava com os muçulmanos, tanto mais quanto alguns homens da sua própria família, desde logo seu pai, se incorporavam no movimento das cruzadas. Bem diferente haveria de ser, contudo, quando habitasse uma terra de que eles eram os vizinhos próximos. Assim, a par de alguma apreensão, não lhe causaria admiração a recente razia de Soure (1144), bem perto da Coimbra que seu marido fizera centro de sua corte e onde protegia obras tão importantes, como dispendiosas, tais o mosteiro de Santa Cruz e a catedral. Da razia de Soure, lhe viria a notícia da sorte do presbítero Martinho, levado em cativeiro para Córdova, onde acabaria por falecer. De par dessas notícias preocupantes, outras viriam, como o caso de Leiria. A concessão de foral a essa localidade, em 1142, e a atenção dispensada aos Templários, eram bem o sinal das preocupações com essas terras do Sul e da estratégia acerca da segurança do território. Com elas se ligavam os problemas que Santarém e Lisboa, ainda em poder muçulmano, representavam para o recente reino de Portugal e com os quais a jovem Mafalda não tardaria a familiarizar-se, se já não as conhecesse, por mercê das conversações acerca do seu casamento.

Tudo problemas de um reino, de um rei solteiro, em busca de uma rainha. 


\section{O casamento de D. Afonso Henriques}

A primeira referência à presença de Mafalda de Mouriana em Portugal, como mulher de Afonso Henriques, rei dos portugueses, é de 23 de Maio de 1146. Equivale a dizer que Afonso Henriques era um homem bem maduro quando contraiu matrimónio, pois terá nascido ao redor de 1109; para a época e os seus costumes, a sua idade era avançada para a ocorrência do acto.

Não há forma de saber a razão do adiamento do casamento do primeiro rei de Portugal. Mas importa questionar o alcance da notícia que, transmitida pelo Livro Velho de Linhagens, de finais do séc. XIII, ultrapassou séculos, e que informa de que o rei D. Afonso [Henriques] de Portugal teve um filho, Fernando Afonso, com D. Chamoa Gomes, de Pombeiro, viúva, mãe de filhos, e monja no mosteiro de Vairão ${ }^{3}$. A senhora era membro da mais relevante nobreza galaico-portucalense. Sua mãe era filha do conde Gomes Nunes, dito de Pombeiro nos livros de linhagens, e da condessa Elvira Peres, filha do conde Pedro Froilaz, aio do imperador Afonso VII. O nascimento de Fernando Afonso deve poder situar-se pela década de 1130, pois que ele subscreveu documentação de seu pai desde 1159 e foi seu alferes entre 1169 e 1172. Não se conhece, porém, o tipo de relação que o rei manteve com Chamoa Gomes: acidental? passageira? Ou, bem ao contrário, seria coisa firme, com futuro? Se assim era, porque razão acabou (se acabou...) ou, pelo menos, não se tornou oficial? Alguém teria desviado Afonso Henriques desses amores? Se sim, qual a razão? Acaso a presença de forças nobiliárquicas diferentes (senão antagónicas) ao lado do rei de Portugal? Por sinal, o percurso de vida do pai de Chamoa Gomes fez-se ora ao lado de forças da Galiza ou de Castela, ora de Portugal. Pode ter acontecido que tal mutabilidade não fosse bem aceite por aqueles que mais fiéis se mantinham a D. Afonso Henriques. Ou, muito simplesmente, tudo terminou porque Chamoa Gomes faleceu?

O casamento tardio do rei de Portugal coloca ainda o problema do adiamento da presença de um herdeiro para o rei e reino de Portugal. Se

\footnotetext{
3 LV 1B6-7.
} 
a autonomia da terra portuguesa era uma incógnita, em si mesma, à afirmação do chefe dos portugueses exigia-se-lhe que também se preocupasse com a necessidade do prolongamento da sua obra, através de um herdeiro.

\subsection{A escolhida: Mafalda de Mouriana}

As dúvidas acerca da demora do casamento de Afonso Henriques só têm paralelo na ausência de testemunho inequívoco que esclareça a escolha de Mafalda de Mouriana e Sabóia para primeira rainha de Portugal.

Por isso, a primeira questão consiste em saber-se quem era, afinal, a filha do conde Amadeu de Mouriana que, vinda da Sabóia distante, chegou a Portugal, em 1146, para desposar o primeiro rei deste jovem reino. Logo um outro se lhe segue: como se chamava, afinal, a mulher do primeiro rei de Portugal, por outras palavras, a sua primeira rainha?

Embora a historiografia portuguesa sempre se lhe refira como Mafalda, o certo é que nem todas as formas que o registo do seu nome conheceu, a autorizam. Tomando por base os documentos da chancelaria de seu marido e uma fonte coeva, do final de sua vida, os Annales domni Alfonsi portucalensis regis (Anais de D. Afonso Henriques, rei dos portucalenses) ${ }^{4}$, ao lado do nome Mafalda é admissível a forma Matilde, cuja equivalência, aliás, a versão breve da Chronica Gothorum indica, "Matildam, vel Mafaldam" . Registe-se, a propósito, que a tradição onomástica de que o seu nome é devedor, a da casa de Albon, no Viennois, obriga a considerar a forma de Mathilda. Assim, só o respeito pela tradição justifica a forma Mafalda.

Mas outros problemas envolvem a ligação de Mafalda de Mouriana a Portugal. Um dos primeiros liga-se à escolha de uma mulher na casa de Mouriana - Sabóia, ou apenas de Mouriana (pois este é o único título que a chancelaria portuguesa refere para Amadeu III, pai de Mafalda, embora ele possuísse outros), para esposa do rei de Portugal.

\footnotetext{
${ }^{4}$ BLÖCKER-WALTER, M., 1966, p. 151-161.

5 PMH. Scriptores, p. 14.
} 
Na verdade, se o matrimónio do rei de Portugal aconselhava uma distanciação da tutela do imperador Afonso VII, seu primo, como já o entendeu a cronística medieval ${ }^{6}$, certo é também que nas casas reinantes da Hispânia, ao tempo, seria difícil achar candidata conveniente ao rei de Portugal, ou por questões de idade, ou porque já comprometidas.

A esposa escolhida para o rei de Portugal era filha de Amadeu III, conde de Mouriana (1103-1148), marquês na Itália e (1. ${ }^{\circ}$ ) conde de Sabóia, por concessão imperial, e de D. Matilde de Albon.

A família permitiria amplas relações a Afonso Henriques. Sua esposa era neta paterna de Humberto II de Mouriana e de Gisela de Borgonha (condal), prima de Luis VII, rei de França, através de sua tia Adelaide, mulher de Luís VI, e ainda prima do imperador de Leão, embora em grau mais afastado, pois que Raimundo de Borgonha (condal), o pai de Afonso VII, era irmão de Gisela de Borgonha, sua avó. Eram ainda irmãos de Guigo de Borgonha, arcebispo de Vienne, o futuro papa Calisto II e o grande vencedor da "questão das investiduras". Mafalda era ainda sobrinha-neta da imperatriz Berta, esposa de Henrique IV, o da jornada de Canossa. Já no séc. XII, Adelaide, irmã de Amadeu III de Mouriana (logo, tia da rainha Mafalda de Portugal), casava com Luís VI, rei de França. O filho e sucessor de Amadeu, Humberto III, acordaria o enlace de outra sua irmã, Alice, com o futuro João Sem Terra, união que só não se efectuou pela morte prematura da jovem de Mouriana.

Quanto aos domínios territoriais, se a fortuna de sua casa vinha de longe, do tempo de Humberto I, o das Mãos Brancas, tetravô de Mafalda, tornado $\left(1 .^{\circ}\right)$ conde de Mouriana por mercê do imperador Conrado II, o seu crescendo está bem patente na presença do futuro Amadeu III de Mouriana na cerimónia de coroação imperial de Henrique V, pelo papa Pascoal II, em Roma, em 1111. Entretanto, a família alcançara o domínio do Vale de Susa e do Piemonte, possessões acompanhadas de um engrandecimento da sua prosápia com o título de "marquês de Susa" ou "marquês na Itália", logo seguidos do alargamento dos domínios pela região de Vevey, estratégica entre a França, a Alemanha e a Itália e que cometia, à família, a responsabilidade da guarda das gargantas do Mont-Cenis e do Mont-Joux (Grande

\footnotetext{
${ }^{6}$ Crónica Geral de Espanha de 1344, IV, p. 234; Crónica de Portugal de 1419, p. 34.
} 
São Bernardo). Ainda por casamento, agora de Amadeu II com Joana de Genebra, a família veria chegar-lhe as regiões de Seyssel e Valromey.

Noutro campo, os de Mouriana haviam de procurar brilhar nas acções mais distintas do seu tempo. O próprio Amadeu III participou na segunda cruzada, capitaneando uma armada organizada pelo papa Eugénio III e pelo imperador Conrado III, com partida de Brindisi, em 1146. Faleceu no regresso, em Nicósia, na ilha de Chipre, dando mais honra à família, quiçá, até, com a alteração do seu brasão de armas, nas quais, ao tempo, a cruz substituiu a águia, em memória desse feito, que lhe valia também o cognome de o cruzado da Sabóia. Por esse tempo, já sua filha mais velha, Mafalda, era rainha de Portugal.

Dentre as memórias que Amadeu III deixou na sua terra, ressalta a protecção dispensada a fundações monásticas, com a fidelização dos seus abades e priores. Dentre elas, distingue-se a abadia de Notre Dame de Hautecombe, cisterciense, filha de Claraval, que se havia de afirmar como segundo e principal panteão da família de Sabóia. Aí achariam a última morada os membros de sua família, desde Humberto III, filho do fundador, até ao último rei de Itália, Humberto II (†1983), que o destino trouxe a Portugal, a terra onde foi primeira rainha uma sua remota antepassada, a senhora de quem tratamos.

Não era menos distinta a ascendência materna de D. Mafalda. Por esse lado, pertencia à família dos condes de Albon, ilustre estirpe do Viennois. Sua mãe, Mafalda (ou Matilde), de Albon, era filha de uma outra Matilde, falecida por 1143, e que, ao chegar à casa de Albon, carreava um ilustre passado, pois que fora a esposa do rei Conrado de Itália, o filho primogénito do imperador Henrique IV e de Berta de Mouriana, falecido em vida de seus pais. Na casa de Albon, casaria com o conde Guigo III. Este, recebera, em feudo, cerca de 1029/1030, o condado do Viennois, donde partiria um importante movimento de alargamento territorial da família. Por sua vez, Matilde de Albon, mãe de Mafalda de Mouriana, era irmã de Rogério II da Sicília, seu primeiro rei e unificador das possessões normandas de Itália, e ele próprio, por sua vez, tio de Afonso Henriques, uma vez que estava casado com a infanta Elvira de Leão, uma meia-irmã de sua mãe, Teresa de Leão. Ainda por linha materna, Mafalda de Mouriana era bisneta de Inês de Barcelona, filha do conde Raimundo Berenguer, o Velho, o que a fazia parente do monarca de Leão, através da esposa deste, Berengária, filha de Raimundo Berenguer III e sobrinha de Inês. 
Tal quadro de relações e de protagonismo junto dos grandes do tempo, leigos e eclesiásticos, demonstram bem que a terra de Mouriana-Sabóia onde nasceu D. Mafalda, futura rainha de Portugal, não era uma entidade política insignificante na Europa do seu tempo. Bem como, no seu conjunto, todos estes elementos familiares tornavam Mafalda de Mouriana (ou Sabóia, como a tradição a havia de consagrar) bem mais próxima da Península e até de Portugal, do que a geografia poderia fazer crer.

Apesar de tanta e reconhecida prosápia, a documentação portuguesa, no geral, não the deu correspondente eco. Quando se refere à estirpe da rainha, apenas o faz por relação a seu pai "conde Amadeu de Mouriana", ou até, simplesmente "conde Amadeu".

\subsection{O casamento de Afonso de Portugal e Mafalda de Mouriana}

No entanto, em Portugal produziram-se e guardaram-se outras referências à rainha que, em simultâneo, louvam a sua família. Alguns registos oriundos do mosteiro de Santa Cruz de Coimbra e do mesmo século em que reinou, consideram-na ilustríssima e de nobilíssimo nascimento, filha do ilustríssimo conde Amadeu ${ }^{7}$. Mas não foram suficientes para a criação e transmissão de uma memória forte e vincada no reino de Portugal e mesmo na sua descendência. Sinal bastante dessa débil lembrança é o testemunho de um seu descendente, do séc. XIV, D. Pedro, conde de Barcelos, filho bastardo do rei D. Dinis, que, no nobiliário das famílias portuguesas a confundiu com uma linhagem peninsular ${ }^{8}$. E seria esta a ideia que havia de persistir, retocada pelo tempo, como espelha a Crónica de 1419, que a considera "da mais alta linhagem de Espanha"9.

Seja como for, são muito outros os problemas acerca da presença de D. Mafalda em Portugal. Uma, a primeira e fundamental, liga-se às razões da sua escolha para rainha de Portugal. Temos por certo que não houve um

\footnotetext{
7 BLÖCKER-WALTER, M., 1966, p. 156.

8 LLCDP 7A18-19, 7B13, 10A8-9.

9 P. 34.
} 
motivo próprio, determinante, antes foi o resultado de um vasto conjunto de relações externas, de uma parte e de outra.

Ignoram-se, por completo, todas as diligências que levaram ao casamento de Afonso Henriques com Mafalda de Mouriana. Desconhecem-se assuntos tão complexos e interessantes como o nascimento da ideia, a formulação de uma proposta, os seus negociadores, as suas condições, a vinda de Mafalda, a sua recepção em Portugal.

O bom termo do processo exige que só poderia ter recomendado e apresentado os projectos do rei de Portugal, perante uma casa estrangeira, quem o conhecesse, quem afiançasse a genuinidade e a grandeza da sua ambição. Da mesma maneira, é lícito interrogarmo-nos acerca da iniciativa ou de uma qualquer proposta a D. Afonso Henriques para a escolha da casa de Mouriana-Sabóia.

Sendo por demais conhecida a influência, ou o envolvimento mesmo, de D. João Peculiar, arcebispo de Braga, em muitos dos sucessos do reinado de D. Afonso Henriques, embora nada prove a sua participação no caso do casamento do rei de Portugal, há, contudo, um conjunto de pequenos indícios que podem incluir o arcebispo nesse processo. Por 1143-1144, D. João Peculiar fazia caminho de Roma, o que bem podia proporcionar uma ida à corte de Amadeu de Sabóia para apresentar uma proposta (ou uma resposta) de casamento de D. Afonso Henriques com sua filha Mafalda. Além disso, depois de breve ausência da documentação portuguesa, o arcebispo reaparece em 1146, por ocasião do primeiro sinal da presença de D. Mafalda em Portugal, isto é, 23 de Maio de 1146. Assim, parece poder afirmar-se a inclusão do arcebispo de Braga no séquito que acompanhou D. Mafalda, de sua terra a Portugal.

Ao mesmo tempo, verifica-se todo um conjunto de informações à volta dessa primeira presença de D. Mafalda em Portugal que se liga, mais ou menos directa ou indirectamente, à ordem de Cluny. Logo esse primeiro documento que atesta a presença de D. Mafalda em Portugal é relacionado com Cluny, através da ligação do mosteiro de Vimieiro (c. Guimarães) ${ }^{10}$ a essa grande casa da Cristandade, pela doação que, em tempo, lhe fora

10 DR 214. 
feita pela mãe do rei de Portugal, e que agora Mafalda e Afonso confirmavam. Por outro lado, é sabido que, pelo tempo próximo da chegada de D. Mafalda a Portugal, andou, em visita, pelos mosteiros da Hispânia, o abade cluniacense Pedro, o Venerável, figura bem conhecida na corte de onde Mafalda era oriunda. Se não veio a Portugal, é conhecida a presença da irmã do rei de Portugal no seu séquito, em Leão. Isto é, tudo concorre para uma intervenção de Cluny, através do seu abade Pedro ${ }^{11}$, no estabelecimento da aliança que o casamento de Afonso Henriques representou ${ }^{12}$. Além da coincidência da primeira presença de Mafalda em Portugal num documento com interesse a Cluny, ele guarda também a memória da estadia de testemunhas do reino de Leão e de gente de nome francês. Se tudo isto parece ir além da mera casualidade, deixa muito por explicar, tal como a origem da iniciativa do enlace matrimonial de Afonso de Portugal e Mafalda de Sabóia e o papel que, eventualmente, desempenharam tanto D. João Peculiar como Pedro o Venerável, no sentido da sua concretização.

No mundo de interrogações que é este casamento, outras questões ficam sem resposta: quando se realizou? Quem, de Portugal, foi buscar Mafalda ao palácio de seu pai? Quem a acompanhou a Portugal? Por onde entrou, em Portugal? Onde a esperou o rei, seu prometido ou esposo?

Embora sem certezas absolutas, a questão que obtém resposta liga-se à data provável do casamento. Segundo informação que pode retirar-se do De expugnatione Scalabis, relato da conquista de Santarém aos mouros pelo rei D. Afonso Henriques, à sua data (que o seu anónimo autor situa em 15 de Março de 1147), ainda não era passado um ano sobre o dia em que o rei de Portugal tomara Mafalda por esposa. Com base neste informe e de um modo mais vago ou mais preciso, os autores têm considerado a Primavera como o tempo dessa celebração ${ }^{13}$ ou o da chegada de Mafalda a Portugal, já casada por procuração, como era comum, ao tempo, o que levaria a remontar o casamento ao ano anterior, de $1145^{14}$.

\footnotetext{
11 MATTOSO, J., 2006, p. 162.

12 MARQUES, M. A.; SOAlHEIRO, J., 2008, p. 214-217.

13 MATTOSO, J., 2006, p. 158.

14 MARQUES, M. A.; SOALHEIRO, J., 2008, p. 219-220.
} 
Quanto à vinda e à chegada de Mafalda de Sabóia a Portugal, se virmos nas testemunhas estrangeiras do documento que pela primeira vez aqui a noticia, gente do séquito que a acompanhou, poderemos perceber na presença do "bom camareiro cluniacense" o sinal inequívoco da presença de um delegado da grande abadia de Borgonha, ao acto, em Portugal, fosse ele um franco ou um hispânico.

$\mathrm{Na}$ completa ignorância, fica-nos, todavia, o local por onde a rainha e o seu séquito entraram em Portugal, quem e onde a esperaram. Se o primeiro documento que assinala a sua presença, em Portugal, e a proximidade do mosteiro beneficiado à cidade arquiepiscopal puder servir de referência, conjugada com a presença do arcebispo de Braga, teríamos que concluir que tudo se passou no Norte do território português; porém, pela data dos acontecimentos, não pode excluir-se que também Coimbra apresentava memórias e pergaminhos bastantes à excelência da senhora e ao significado do acto que a trazia a Portugal.

\subsection{Mafalda de Mouriana, rainha de Portugal}

À sua chegada a Portugal, Mafalda de Sabóia estaria em plena juventude. Pelo facto de ter sido mãe dez meses após a sua primeira referência em documentos portugueses, ao lado de seu marido, terá de se admitir que saiu de casa de seus pais em idade núbil, como, aliás, seria o comum. Pela mesma razão, somos levada a admitir que o seu nascimento deve ter ocorrido pelos primeiros anos da década de 1130, quando muito cerca de 1133 ou próximo. Mafalda era, por isso, bem mais nova que seu marido; este era um homem bem maduro e experimentado, pois já teria passado os seus 35 anos de idade, de uma vida intensa, vivida nos desafios que a defesa e o alargamento da sua terra lhe impunham. Apesar dessa assinalável diferença de idade, em Portugal Mafalda seria a esposa e companheira de seu marido, a consorte do seu reino ou a filha do conde Amadeu de Mouriana, lembrança grata dos elos que a ligavam à sua casa de origem.

Nada se conhece sobre o aspecto físico da primeira rainha de Portugal, nem tal seria espectável dada a parcimónia e o carácter das fontes da época. 
No entanto, se entendermos ver o seu rosto retratado num desenho da pena de João Pedro Ribeiro, que tenderá a reproduzir um outro, patente num documento original do mosteiro de Pombeiro, em sinal rodado da rainha, com um rosto e a legenda Regina, (acompanhando um outro, do rei Afonso Henriques ${ }^{15}$ ), apenas poderemos dizer que ela tinha um rosto comprido, no qual se salientava o nariz fino e alongado.

Outro elemento ignorado sobre a rainha e o seu casamento se junta aos já indicados. Trata-se, agora, de algo que possa informar acerca das condições do contrato nupcial. Nada se conhece que possa esclarecer as arras que era de uso o noivo conceder àquela que tomava por mulher, sabendo-se, porém, que já estavam em uso na Península, ao tempo.

Bem depressa a união de Afonso Henriques com Mafalda de Mouriana e Sabóia começou a dar os seus frutos. Em menos de um ano de casamento, D. Mafalda cumpria, na perfeição, o fim a que uma rainha se destinava: dar herdeiro a seu marido, varão, tanto quanto possível. Em auspicioso prenúncio, em 5 de Março de 1147 nascia o primeiro filho do régio casal, que ganhava o nome de Henrique, em memória de seu avô paterno. O tempo veria o seu casamento frutificar em mais filhos; em Junho de 1155, são três os que acompanham o régio casal, Sancho, Urraca e Mafalda, pois que era já falecido o primogénito.

E pouco mais sabemos acerca da vida desta rainha; muito poucas foram as lembranças que ultrapassaram os séculos e chegaram até nós. Se é certo que a sua vida foi breve, talvez que as suas memórias tenham sido relegadas pelas de seu marido, bem mais numerosas e impressivas, como se entende, pela necessidade da sua afirmação como o "fundador", o guerreiro, o conquistador e o político.

Das fugazes lembranças de D. Mafalda, salienta-se uma nota, muito antiga, de algo que muito a atingia como mulher, o sofrimento em ocasião de parto, que a levava a "perigo de morte". Registado em velha narrativa oriunda do mosteiro de Santa Cruz de Coimbra, pode bem entender-se pelo auxílio que a força da oração de Teotónio, primeiro prior desse mosteiro, a quem a rainha tributava clara afeição e devoção, lhe proporcionava em momento de tanta aflição.

15 DR, p. C-CI; 253. 
A lembrança perdurou, sendo recolhida e ampliada na cronística crúzia. Frei Nicolau de Santa Maria, seu autor, ao registar a memória do mosteiro de Santa Marinha da Costa (c. Guimarães), reporta a sua fundação à primeira rainha de Portugal e justifica o orago pelo facto de a virgem e mártir Marinha "ser avogada das dores e perigos que passão as molheres nos partos" e, mais ainda, por um voto da rainha Mafalda, paciente de partos "por vezes muito trabalhosos", por ocasião de um especial, no qual se viu "às portas da morte". Mais informa o cronista de que a rainha possuía, e usava, uma relíquia da mesma Virgem, a qual, por sua morte, ficou ao mosteiro de S. Vicente de Lisboa, para protecção das mulheres em tempo de dar à luz ${ }^{16}$.

Quanto às relações que o régio casal cultivava entre si, a memória que ficou significa pouco mais que nada. Por um lado, o seu casamento não foi longo nem a sua descendência numerosa; por outro, o tema é de difícil estudo, uma vez que se liga à esfera das relações privadas. No entanto, se algo de verdade houver na narrativa de um cortesão inglês, Walter Map, que terá tido conhecimento da corte portuguesa, pelo final do séc. XII, o seu relacionamento seria marcado por episódios bem pouco abonatórios do carácter do rei de Portugal. Segundo ele, o rei de Portugal era um homem dado à cólera e ao ciúme, e era também um homem brutal, capaz de espancar a sua mulher, mesmo em estado de gravidez, com uma intensidade própria da loucura e da cegueira do ciúme ${ }^{17}$.

A vida de Mafalda de Mouriana e Sabóia, enquanto rainha de Portugal, decorreu em paralelo com sinais da prática de barregania por parte de seu marido. Pelo tempo do seu casamento, já Afonso Henriques tinha um filho bastardo, pelo menos, Fernando Afonso, filho de Chamoa Gomes, de Pombeiro. Se a falta de notícias impedem uma visão alargada e correcta da situação, as que estão disponíveis indicam que Fernando Afonso apenas subscreveu documentação de seu pai a partir de $1159^{18}$, isto é, após a morte da rainha D. Mafalda. O facto pode dever-se, muito simplesmente, à idade do jovem, mas também pode ter qualquer relação com uma

\footnotetext{
16 CCR, L. VI, p. 325-326.

17 MATTOSO, J., 2006, p. 161-162.

18 DR 271.
} 
atitude da rainha, de menos boa aceitação da presença desse bastardo na corte régia.

Se estiverem certas outras informações, de carácter linhagístico, a rainha D. Mafalda deve ter sofrido, ou pelo menos, tido conhecimento, de um outro desvario de seu marido, embora sem consequências de maior para a família. Trata-se de uma memória registada quer no Livro velho de linhagens, quer no Livro de linhagens do Conde D. Pedro, em título dedicado aos de Sousa, que faz eco de uma atitude de verdadeiro assédio do rei, a uma dama da nobreza, D. Sancha Afonso [das Astúrias], mulher de D. Gonçalo de Sousa, um dos grandes da corte de Afonso Henriques, que deve ter ocorrido antes da década de $1150^{19}$. Apesar de tudo, nada se percebe acerca da reacção da rainha e do entendimento que ela faria desses impulsos de seu marido.

Com uma vida de mulher idêntica à de tantas outras, mais ou menos amada, mais ou menos feliz, por entre a alegria da existência dos filhos, as preocupações de mulher, perante a dificuldade dos partos, e as mágoas de mãe, quando via sofrer ou morrer, pequeninos, os seus filhos, não foi longa a existência de D. Mafalda.

Mesmo sabendo nós que veio a falecer em Dezembro de 1158, a rainha tem a sua última presença activa em Julho de $1157^{20}$. Até ao tempo em que veio a ocorrer o seu falecimento, a chancelaria de seu marido só apresenta o nome da rainha, e apenas na invocação que dela é feita, em dois diplomas da Primavera desse ano de $1158^{21}$. A partir de então, é a ausência total.

D. Mafalda de Mouriana viria a falecer muito provavelmente em 3 de Dezembro de 1158, sendo possível que tenha falecido de parto, tão vulgar era a ocorrência e tão sofredora era a rainha em tais circunstâncias, como se referiu.

D. Mafalda foi sepultada no mosteiro de Santa Cruz de Coimbra, uma casa onde já repousava pelo menos o seu filho primogénito, e cujo claustro tanto teria gostado de conhecer, mas onde o prior D. Teotónio sempre lhe negou a entrada, a ponto de o facto ter sido motivo de verdadeira perseguição, por parte da rainha, segundo memória registada na Vida de São Teotónio,

\footnotetext{
19 PICOITO, P., 2006, p. 251.

${ }^{20}$ DR 262.

${ }^{21}$ DR 269 e 270.
} 
o qual, mesmo assim, não lhe regateava bênçãos e mansidão ${ }^{22}$. No mosteiro, a rainha era recordada em solene procissão sobre o seu túmulo, promovida pela comunidade monástica, à qual se associava o povo e o próprio clero da cidade de Coimbra ${ }^{23}$. Não se conhece o seu epitáfio, mas os Anais do primeiro rei de Portugal incluem uma ementa relativa ao falecimento da rainha que, se não o transmite, lhe está muito próxima. Para além de registar o ano, mês, dia e hora do acontecimento, di-la "ilustríssima e claríssima" e liga-a quer à insigne prole paterna, afirmando-a "nascida do nobilíssimo Conde Amadeu", quer ao rei dos portugueses, de quem era esposa.

Tendo vivido e reinado poucos anos em Portugal, não admira que a memória da rainha Mafalda rapidamente se tenha começado a delir. Num tempo em que interessavam mais as memórias que glorificavam os reis, as suas guerras e vitórias, não admira que a sua lembrança fosse mínima e até a sua identidade adulterada. Já vimos como um seu descendente, o conde D. Pedro, a considerava "da mais alta linhagem de Espanha". Relacionava-a com a estirpe dos de Lara, grande de Castela, parentesco que o mesmo conde retocaria na Crónica Geral de Espanha de 1344, obra onde a considera "filha do conde Manrique de Lara e senhor de Molina”. Tratava-se, claramente, de uma confusão entre a memória da rainha Mafalda e a de sua neta Mafalda Sanches, que os de Lara levaram ao casamento, frustrado, com o rei Henrique I de Castela.

E assim, no esquecimento e na confusão da memória, se adulterava a presença e a lembrança de uma rainha. Se, em vida, Mafalda de Mouriana e Sabóia fora uma sombra, passageira e fugidia, no reino de Portugal, não mais lograva, depois de morta. E se a própria família lhe perdia a lembrança, o seu reino mais não lha tributava.

\section{A acção da rainha Mafalda}

Como muitas outras rainhas ou infantas do seu tempo, D. Mafalda não exerceu qualquer papel digno de especial memória aos homens do seu

\footnotetext{
22 MATTOSO, J., 2006, p. 160-161.

23 MARTINS, A., 2003, p. 260.
} 
tempo, àqueles que haviam de traçar as palavras e os textos que serviriam de memória às gerações por vir. Numa corte dominada por homens, não houve lugar a um protagonismo próprio da rainha.

Temos por certo que D. Mafalda viveu a maior parte da sua vida em Coimbra, pois que, apesar da itinerância que marcava a corte deste tempo, era nessa cidade que D. Afonso Henriques mantinha a sua residência principal, em virtude da "centralidade administrativa que esta cidade detinha", como já escrevemos ${ }^{24}$. Na corte se cruzou com os curiais de seu marido, os mordomos Fernão Peres Cativo e Gonçalo Mendes, de Sousa, os alferes Mem Fernandes, de Bragança, e Pero Pais, da Maia, o chanceler mestre Alberto, talvez o vice-chanceler Paio.

Se o paço em que viveu, na alcáçova da cidade, era idêntico a muitos outros, nos seus espaços públicos e privados, em concreto, nada, ou muito pouco, se conhece acerca dele. Aliás, como acontece com os objectos de uso, nos seus mais diversos fins e utilidades. Nada se conhece que se possa referenciar, com segurança, ao tempo da rainha Mafalda; contudo, não seriam muito diferentes daqueles que se podem referenciar ao tempo de seu filho, o que permite afirmar a existência de luxo e, por certo, requinte, na corte régia, sobretudo na sua mesa 25 .

Em Coimbra, D. Mafalda teve oportunidade de assistir às obras do mosteiro de Santa Cruz e à sagração do altar-mor da sua igreja, em 1150, por D. João Peculiar ${ }^{26}$, e ao início das obras da catedral, o que vale por dizer que se a cerimónia do seu casamento se realizou em Coimbra, ainda teve lugar na anterior igreja maior da cidade.

Além de Coimbra, é muito provável que D. Mafalda tenha conhecido outros lugares do reino de Portugal. Pelos documentos de seu marido, haveríamos de concluir que a rainha Mafalda só conheceu Coimbra e Guimarães $^{27}$, o que é manifestamente pouco. Haveria lugares do percurso entre estas duas importantes localidades onde pousaria a corte, ou lhe

\footnotetext{
242008 , p. 364.

25 MARQUES, M. A.; SOALHEIRO, J., 2008, p. 374-399.

26 GOMES, S., 2007, p. 142.

27 DR 217, 226 e 229.
} 
chamariam a atenção, além de que a tradição guardou memória de uma ligação da rainha a Lamego e sua região. E temos por certo que, alguma vez, a rainha Mafalda desceu até Santarém e Lisboa, localidades cuja fama por certo lhe atrairia a atenção.

A tradição guardou memória de alguma acção da rainha D. Mafalda em Portugal. Liga-se a obras de assistência, entendidas no sentido lato que tinham ao tempo, acolhendo a construção de pontes ou a protecção de barcas de passagem. Entre elas, talvez se possa ter contado uma ponte sobre o rio Douro, cujas obras se terão prolongado, no tempo, como informa o testamento do rei D. Afonso Henriques, em 1179, ao consignar-lhe uma verba, ao cuidado dos monges de Tarouca ${ }^{28}$. Até então, colmatava a sua ausência, na ligação das duas margens, uma barca de passagem, junto a Lamego, cuja instituição a tradição relacionava com a rainha D. Mafalda. Ainda segundo ela, teria sido também a mesma rainha a fundadora de uma albergaria, em Moledo (c. Lamego), para amparo de viajantes e peregrinos, que aí achavam cama, fogo, sal e água, gratuitamente 29 .

Embora tardios, do tempo de seu trineto, o rei D. Dinis, alguns testemunhos associam a memória da rainha D. Mafalda à fundação de uma outra albergaria, também por terras do Norte interior, em Canaveses (c. Marco de Canaveses), e de uma ponte sobre o Tâmega, na mesma localidade. Mantida pelo rendimento da portagem do lugar, a albergaria destinava-se a nove peregrinos, que achariam aí camas "boas e limpas", e recebiam, à entrada ou à saída, lume, água e sal; caso algum aí falecesse, haveria lugar ao seu enterro e a três missas ${ }^{30}$.

As inquirições régias de 1258 registaram um episódio que liga a primeira rainha de Portugal a outras terras da Beira. Em ocasião e por razões que as testemunhas já não recordavam, alguns homens do rei D. Afonso Henriques e de sua esposa cortaram uma mão ao clérigo da igreja de Santa Maria de Canas, na diocese de Viseu. Em reparação de tão bárbara atitude, acrescentaram os mesmos jurados, a rainha concedeu-lhe três casais reguengos

\footnotetext{
${ }^{28}$ DR 334 .

29 FERNANDES, R., apud BARROS, A. M., 2001, 44-45.

${ }^{30}$ LA FIGANIÈRE, F. F. de, p. 222-224.
} 
que aí detinha e uma herdade de cavalaria foreira ao rei e coutou a villa por padrões ${ }^{31}$.

Pelo ano de 1152, a rainha dispensou a sua protecção à igreja de Santa Maria de Abade de Neiva (c. Barcelos), a crer-se numa inscrição que existia nesta igreja ainda no séc. XVIII, hoje desconhecida, e que atestava a sua benemerência ${ }^{32}$.

Contrariando alguma debilidade de algumas destas memórias, apresenta-se bem sólida a lembrança da generosidade da rainha D. Mafalda para com a sé de Coimbra. O registo do aniversário da sua morte, inscrito no Livro das Kalendas, necrológio da igreja catedral de Coimbra, informa de que a rainha distinguiu essa igreja com a dádiva de duas capas e uma mantilha de seda, duas píxides de marfim e, à hora da morte, um scortium de prata, com o peso de nove marcos 33 .

Mesmo com base mais na tradição que em documentos, o exposto acerca das obras de piedade da rainha Mafalda ajuda a aceitar o que o autor da Vida de São Teotónio, escreveu, pouco depois da sua morte (1162): "mulher sensata e bem firmada na fé"34. Com o valor possível de topos literário, também pode significar uma homenagem do seu autor, anónimo cónego de Santa Cruz de Coimbra, ao carácter, à fé e às obras da rainha, tanto mais quando se conhece o seu difícil relacionamento com o santo prior do mosteiro coimbrão.

\section{Os filhos de D. Afonso Henriques e de D. Mafalda de Mouriana}

É do mês de Junho de 1155 o primeiro documento que chegou até nós proveniente da chancelaria régia ${ }^{35}$ no qual são nomeados os filhos do régio casal português, os infantes Sancho, Urraca e Mafalda, intitulados de rei e rainhas, segundo o uso do tempo. No entanto, sabe-se que, à data, estes

\footnotetext{
31 PMH. Inquisitiones, 831, a, b.

32 BARRoCA, M. J., 2001, I, 240, n. ${ }^{\circ} 95$.

33 LK, 2, p. [293].

34 Ed. NASCIMENTO, A., 1998, p. 179.

35 DR 254.
} 
não eram os únicos filhos já nascidos da união do régio casal, bem como se conhece que outros se lhe terão seguido.

Atendendo a alguma contemporaneidade entre a vida de alguns deles e a redacção dos Annales domni Alfonsi Portugallensium regis, nos finais do séc. XII, merece alguma fidedignidade a informação de que a sua prole foi composta por um grupo de seis filhos, três varões e três raparigas ${ }^{36}$. À data da sua realização, eram falecidos três deles, dois rapazes e uma rapariga, informando, o escriba, seu autor, de que esta tinha falecido "in primaeva aetate”, isto é menina. Assim, parece ficar certo que do casamento de Afonso Henriques e D. Mafalda nasceram os infantes Henrique, Urraca, Mafalda/Teresa/Matilde, Martinho/Sancho, Sancha e João.

Sem podermos saber onde foram criados os infantes ou quem teve a seu cargo essa tarefa, é conhecido que, tanto a ama da infanta Urraca, como a do infante Sancho, eram mulheres de Coimbra ou, pelo menos, bem ligadas a esta cidade, local da corte por excelência.

Já a educação dos infantes terá sido feita no seio da nobreza, tendo estado a cargo da família de Ribadouro, pela acção de Teresa Afonso, mulher de Egas Moniz, a ponto de ela própria se ter considerado "nutrix prolis regiae", isto é, ama dos filhos do rei ${ }^{37}$.

Nada se conhece acerca da educação de príncipes, por esta época, podendo, contudo, afirmar-se que o infante herdeiro de bem tenra idade tinha, a seu lado, entre outros oficiais, um capelão e um chanceler que, decerto, se ocupavam de alguma preparação intelectual, bem como o iniciavam nos segredos da governação ${ }^{38}$. Já a sua aprendizagem das coisas da guerra bem pode ter sido feita junto dos nobres da família e do ć́rculo de D. Teresa Afonso.

Henrique, o primogénito dos primeiros reis de Portugal, nascido em Março de 1147, em ambiente de bom auspício para as conquistas que seu pai preparava (Santarém e Lisboa), faleceu em criança, proporcionando, assim, a chegada do irmão Martinho ao poder. Poderá ter sido em função da morte de Henrique que se assistiu à mudança do nome do infante

\footnotetext{
36 BLÖCKER-WALTER, M., 1966, p. 157.

37 Apud REIS, B., [1936], p. 15-16.

38 MARQUES, M. A.; SOALHEIRO, J., 2008, p. 257.
} 
Martinho para o de Sancho, nome mais de acordo com a tradição de nome real. É muito provável que o infante Henrique tenha sido o primeiro dos membros da família real a encontrar o eterno repouso no mosteiro de Santa Cruz de Coimbra.

Este mesmo destino de uma morte prematura, em idade infantil, atingiu os infantes João e Sancha. O primeiro não é, sequer, referido na documentação de seu pai e não se lhe conhece data de nascimento, nem ano de falecimento. A sua existência é atestada por um velho livro de memórias do mosteiro de Santa Cruz de Coimbra, que acolheu a notícia da sua morte no dia 25 de Agosto, de um ano que os estudiosos crêem ter sido 116339. Por sua vez, a infanta D. Sancha é considerada como a última filha dos primeiros reis de Portugal. É provável que tenha nascido em finais de 1158 e pode admitir-se que a morte da rainha Mafalda esteja ligada ao seu nascimento. Tem uma presença muito fugidia nos documentos de seu pai, que testemunham a sua existência em 1159 ou, quando muito, entre 1159 e $1162^{40}$. Por isto mesmo, ela deve ser a filha falecida menina que referem os Anais do rei D. Afonso de Portugal.

Deste modo, são apenas três os filhos de Mafalda de Mouriana e Sabóia e Afonso I de Portugal que chegaram à idade adulta, tendo, por isso, gerado uma memória que lhes concedeu um lugar na história da sua terra.

Primogénita das infantas, D. Urraca foi a escolhida para esposa do rei Fernando II de Leão, seu parente em grau proibido pelas regras canónicas do tempo. Como tantos casos ao longo do tempo, com mulheres da sua condição, o seu matrimónio foi uma questão política entre os dois reinos. Deve ter-se inserido na tentativa de resolução das questões à volta de Límia, abordadas na "Paz de Lérez". Não se sabe quando se realizou o casamento, mas o nome da rainha surge nos documentos de seu marido a partir de Julho de 1165. Pouco se conhece da sua vida como rainha de Leão. Foi mãe do herdeiro do trono em 1171. Era o futuro rei Afonso IX de Leão, monarca que ficaria ligado a acontecimentos importantes ou controversos, como a primeira reunião de cortes em Leão (1188), a fundação da universidade

\footnotetext{
39 CASTRO, A., 1996, p. 294.

40 DR 290, 291 e 292.
} 
de Salamanca, a conquista de Alcântara, ou alianças com os muçulmanos, ainda que esporádicas. Em razão do parentesco próximo entre os cônjuges, Urraca de Portugal e Fernando II de Leão viram o seu casamento desfeito, por ordem papal, em 1175. No entanto, D. Urraca permaneceu em Leão, recolhida à Ordem de São João do Hospital. E foi por aí que acompanhou a vida de seu filho, até falecer já nos inícios do séc. XIII.

Bem diferente destino teve a outra filha de D. Mafalda e D. Afonso Henriques, aquela que terá sido a secundogénita das infantas e que na pia baptismal recebeu o nome de sua mãe, Mafalda. Citada no primeiro documento de seu pai em que são enumerados os infantes (1155, Junho), o seu nome é muito pouco presente na colecção diplomática que nos chegou do primeiro rei de Portugal. Deve ter nascido em 1149, pois que em 1160 já era de idade núbil. No Liber fidei Sancte Ecclesie Bracharensis, importante códice da catedral de Braga, organizado no séc. XIII, ficou registado o contrato de casamento desta infanta com o filho primogénito de D. Raimundo, conde de Barcelona ${ }^{41}$, casado com a rainha Petronilha de Aragão. Foi lavrado em Tui, em 30 de Janeiro de 1160. Nessa cidade se realizou o encontro das luzidas embaixadas de ambas as partes e se celebraram os esponsais, por procuração do noivo, representado por seu pai. Entre festas e manifestações de júbilo se perde o futuro do enlace assim projectado, facto que a historiografia tem aceitado como indício de morte da infanta portuguesa e causa de insucesso desta primeira tentativa de aliança entre Portugal e Catalunha e Aragão. No entanto, ela volta a estar presente na documentação de seu pai em Março de $1164^{42}$, posto o que o seu nome desaparece, para dar lugar a um outro, também de mulher, agora Teresa, a partir de Novembro de $1165^{43}$. Portanto, será sempre de questionar a causa do insucesso matrimonial e, a admitir-se um infortúnio, tem que aceitar-se que ele também pudesse ocorrer pelo lado do noivo. Porém, sobre a infanta recairiam consequências, como o seu regresso à casa paterna. Ora, esta hipótese coaduna-se muito bem com o aparecimento de um novo nome

41 LF 218.

42 DR 286.

43 DR 288. De notar que mereceu a classificação de "Falsificação" o DR 278, de Agosto de 1161, em que surge o nome de Teresa. 
de mulher na chancelaria régia portuguesa. Regressada a Portugal, Mafalda transmutaria o seu nome a Teresa, num desejo de esquecimento e renovação. Então, Mafalda e Teresa seriam uma e mesma infanta, como já foi proposto também ${ }^{44}$. Aliás, a hipótese até nem tem muito de inovador, em vista dos dois casos, indubitáveis, de mudança de nome entre os filhos de D. Afonso Henriques e, por certo, tantos outros, pelo tempo, que nos ficaram desconhecidos.

Em nossa opinião, esta hipótese até vai bem com um outro elemento que já valorizámos em obra publicada em $2008^{45}$. Aí, colocámos em realce o facto de D. Teresa ter sido senhora de Montemor, por doação de seu pai, em data que se ignora, mas que há-de ter acontecido após 1166. O facto tanto pode colher valor neste contexto, como num outro, um pouco mais tardio. No primeiro, aquela doação pode ter acontecido por relação com o seu regresso ao reino, vinda de Barcelona, e da sua especial situação. Na sua condição de infanta, regressada de uma terra onde não servia, importaria dar-lhe casa, autonomia, que passava pela posse de bens próprios. No segundo, pode ter acontecido quando Teresa se tornou a única filha capaz de se assumir como herdeira do reino, em caso de necessidade isto é, após 1175, ano da entrada de D. Urraca na Ordem do Hospital, na sequência da anulação do seu casamento com Fernando II de Leão.

Por último, a hipótese de identificação da infanta Mafalda com a infanta Teresa, embora não seja - nem possa ser - mais que isso, condiz com as informações que a importante fonte da época, que são os Annales domni Alfonsi Portugallensium regis, afinal memória do rei, seu pai, de sua família e do seu tempo, nos transmite acerca do número de filhos de D. Afonso Henriques e de Mafalda de Mouriana, como referimos. Ao indicar o número de seis filhos, três varões e três raparigas, como o fruto da sua união, exige a identificação de duas personagens, que bem podem ser as infantas Mafalda e Teresa. Se o seu autor não refere a infanta Mafalda, não é crível que, presente em Coimbra e conhecedor, forçoso, da família real, desconhecesse a sua existência, bem como a sua ligação matrimonial à casa

\footnotetext{
44 BLÖCKER-WALTER, M., 1966, p. 56-57.

45 MARQUES, M. A.; SOALHEIRO, J., p. 125.
} 
de Barcelona. Aliás, ele escreveria, até, em tempo em que uma outra ligação matrimonial, a de Sancho e Dulce de Aragão, unia o reino de Portugal e a família reinante em Aragão e Catalunha, o que faria recordar essa primeira. A sua omissão relativamente ao nome da infanta Mafalda e a esse momento da sua vida pode explicar-se por, na ocasião em que ele escrevia, ela ser Matilde (nome que também omite, preferindo o de Teresa) e se achar casada com o conde da Flandres. Porém, se a nossa hipótese não corresponder, em nada, à realidade, ficará sempre a dúvida do que aconteceu à infanta D. Mafalda após 1164.

Fosse como fosse, a infanta D. Teresa é referenciada a partir de 1165 , como afirmámos. Se ela não for a infanta Mafalda que já conhecemos, o primeiro problema que se pode colocar acerca desta infanta é o seu aparecimento tão tardio na documentação. Pelo protagonismo que assumiu a partir de 1169-1170, não poderia ser tão jovem quanto esse tardio aparecimento poderia fazer crer. Em nossa opinião, esta será, até, uma outra razão para vermos em D. Teresa a infanta Mafalda cujo rasto perdemos há pouco.

Surgida de repente, na documentação, é muito pouco o que sabemos da sua vida. A indicação do seu mordomo, em 1175, é a prova de que possuía casa e oficiais próprios. Ao mesmo tempo, era senhora de um conjunto de bens, de que se destacava Ourém (a que concedeu foral em 118046) e Montemor, talvez, também, Tábua ${ }^{47}$.

Porém, o mais importante protagonismo da infanta Teresa surgiu em toda a força a partir de 1169, depois do desastre de Badajoz. Nessa circunstância dramática para o reino de Portugal, a infanta tornava-se um precioso tesouro na estratégia política do pai, falho de qualquer sucessão, além dos seus dois filhos, Sancho e Teresa, solteiros e sem herdeiros.

O futuro de Teresa sofreria alteração significativa após o casamento de seu irmão Sancho, em 1175, com Dulce de Aragão. Em 1184, assegurada a sucessão do irmão, ela saiu de Portugal, para casar com Filipe de Alsácia, conde de Flandres e senhor de Vermandois. Muitas razões poderão ter concorrido para este enlace, das quais não será de arredar o conhecimento

\footnotetext{
46 PMH. Leges, p. 420-421.

$47 \mathrm{PMH}$. Inquisitiones, $781 \mathrm{~b}$.
} 
que o pai do noivo teria das terras e da corte de Portugal, pela sua passagem a caminho da Terra Santa, ou as notícias que, sobre elas, correriam, na Cristandade, levadas por discípulos de São Bernardo, ou, ainda, algum interesse da coroa de Inglaterra, ainda aparentada com a casa de Alsácia, em alianças nestes confins da Cristandade ${ }^{48}$.

Fosse como fosse, o casamento contratou-se, Teresa saiu de Portugal, rumo à Flandres, os noivos receberam-se por palavras de presente, em Bruges, em 1184. Teresa recebeu um importante dote, com destaque para vilas e cidades, como Saint-Omer, Lille, Nieppe, Cassel, Furnes, Douai, Bruges, Gand, Ypres, algumas em clara fricção com o rei de França e as suas pretensões sobre os seus domínios.

Chegada à nova terra, Teresa transmudou o nome em Mahaut, adoptando, afinal, uma das formas do seu nome original, Mafalda ou Matilde. Foi esta última (Mathildis) que consagrou no selo de que usou.

Na Flandres, a condessa-rainha Matilde desdobrou a sua atenção pelo acompanhamento do marido nas tarefas da governação e em algumas outras, próprias das mulheres poderosas do tempo, como a fundação de hospitais para doentes pobres, como o de Ypres. Com seu marido, Matilde foi próxima de Claraval, o mosteiro de São Bernardo, que distinguiram com doações e onde elegeram sepultura, em capela fundada por Filipe de Alsácia.

Matilde ficou viúva em 1191, por morte de seu marido, na cruzada, em São João de Acre, na Palestina. Em breve (1193) contrairia segundas núpcias, com Otão III, duque de Borgonha, a quem ainda a uniam laços de parentesco, em grau afastado, mas, ainda assim, proibido, pois que Otão III da Borgonha era filho de Hugo III, conde de Albon, casado com Beatriz d'Albon, herdeira do condado e prima em segundo grau da infanta portuguesa. O impedimento de parentesco e as desavenças do casal levariam, em breve (1195), ao divórcio do casal.

Entretanto, Matilde, afastada do poder na Flandres, seguia atentamente o percurso de Balduíno, sobrinho de seu defunto marido, a quem coubera a Flandres. Sobretudo, interessavam-lhe as relações dele com o astuto e

48 AZEVEDO, L. G., 1942, p. 147-150; LOMAX, D. W., 1964. 
cobiçoso rei de França, Filipe o Augusto, interessadíssimo nas terras de Flandres. A partida de Balduíno, na cruzada, a sua ascensão a imperador de Constantinopla e a menoridade de suas filhas, chamaram Matilde, de novo, à política flamenga. Ou buscou, ou a sorte lhe ofereceu, a esse fim, um seu sobrinho, o infante Fernando, filho do rei de Portugal, Sancho I, e de sua esposa, D. Dulce. Ela faria dele o instrumento da sua política e da sua vingança sobre o rei de França.

Em 1210, o infante português já estava na corte de França, onde uma sua cunhada por afinidade, Branca de Castela, era mulher do infante herdeiro. Ganha a confiança do rei de França, Fernando casou, em 1212, com Joana de Flandres, a filha herdeira de Balduíno, conde de Flandres e Hainaut e defunto primeiro imperador latino de Constantinopla. Matilde tornar-se-ia a sua mentora e protectora; alguns cronistas do seu tempo haviam de acusá-la de proteger os de sua terra, em que avultava seu sobrinho. É provável que tenha tido também alguma intervenção numa hipótese de casamento entre o rei inglês João Sem Terra e sua sobrinha Sancha, filha de D. Sancho I, pelos anos de 1199 ou 1200, bem como não lhe terão sido alheias as negociações que conduziram ao casamento de uma outra, Berengária, com o rei da Dinamarca, em 1214.

Mas foi relativamente a Fernando que Matilde da Flandres de Portugal mais se empenhou. Quando ele, sobretudo por virtude da terra que governava, entrou na política do seu tempo, marcada pelo antagonismo entre franceses e ingleses, e caiu cativo do rei de França, na batalha de Bouvines (1214), Matilde não recuou, nunca, na sua defesa. A atitude valeu-lhe uma memória negativa nas crónicas do tempo, especialmente na que saiu da pena de Guillaume le Breton, cronista de Filipe o Augusto.

Apesar dos seus esforços, pessoais e financeiros, a rainha Matilde morreu sem a alegria da libertação de seu sobrinho. Quando morreu, em 6 Março de 1219, afogada em lama, no pântano em que tombou a sua liteira, perto de Furnes, ainda Fernando era um dos prisioneiros da torre do Louvre, em Paris.

Matilde, Flandriensis comitisse ou, noutra forma, regina Portugalensis, foi sepultada no mosteiro cisterciense de Dunes, na Flandres, de protecção dos de Alsácia, tendo sido, posteriormente, trasladada ao mosteiro de Claraval, onde achou sepultura junto a seu marido. 
A infanta Teresa de Portugal, volvida condessa Matilde na Flandres, viúva de Filipe de Alsácia, deixou memória de uma mulher activa, persistente, tenaz, dedicada aos interesses dos seus, familiares e amigos, gestora perspicaz e astutamente generosa dos seus tesouros. Foi figura cimeira na política do seu tempo, de par com os grandes que a dominavam, sobretudo o rei de França e o rei de Inglaterra. Longe da sua terra, ocupada nos assuntos correntes da governação e envolvida nos problemas políticos que dominaram a terra e o tempo em que viveu, Matilde de Flandres não perdeu ocasião de olhar os problemas do longínquo Portugal. Não lhe terá sido estranha a chegada de flamengos ao reino de seu irmão, que os documentos portugueses atestam, por então.

Por último, algumas palavras acerca do infante D. Sancho Afonso. Filho secundogénito de Afonso Henriques e Mafalda de Mouriana e Saboia, nascido alguns anos depois do casamento de seus pais, por um acaso da vida veio a ser o herdeiro do trono, D. Sancho I, segundo rei de Portugal. Nasceu em 11 de Novembro de 1154, em Coimbra. Talvez por esse motivo, recebeu, no baptismo, o nome de Martinho, transmudado a Sancho, em circunstâncias que se desconhecem e que já referimos acima.

$\mathrm{Na}$ sua condição de segundo rei de Portugal, foi também o primeiro herdeiro, sucessor de um rei fundador. Por isso, Sancho era um progénito com futuro incerto, mais envolto na sombra de seu pai que numa aposta de vencedor. Recebia, de herança, um reino recente, com os problemas próprios da situação e o confronto que proporcionava com a memória do rei seu pai; a ele se exigia que estivesse à altura da ambição de seu pai e que desse continuidade ao seu sonho.

A sua figura foi alvo de um estudo próprio e aprofundado, num passado ainda recente ${ }^{49}$. Porém, ao contrário da imagem construída, temos, para nós, que o percurso do seu reinado não desmentiu os méritos de que ele já dera prova ainda em vida de seu pai.

Como rei, Sancho I deixou memória pelo seu grande e importante papel de organizador. Foi relevante a sua acção em prol dos povos, naquilo que eles mais sentiam e, por certo, mais desejavam, que era a definição de regras

\footnotetext{
49 BRANCO, M. J., 2005.
} 
com o poder. As 43 cartas de foral concedidas por autoridade régia, no seu governo, de longe o maior número desses diplomas que algum dos três primeiros monarcas portugueses outorgou, dizem da sua acção. Na produção estereotipada da sua chancelaria, o seu reinado revela-se um tempo novo, na construção da imagem do rei e na concepção do seu poder. A figura do rei é a fonte da ordem, do bem comum, da paz, a raiz da lei e do fisco, o garante da defesa do reino e dos homens. Os forais, que já referimos, foram um bom meio de propagação dessa ideias, tanto melhor quanto era vasto e longínquo da corte o público que alcançavam. Como Maria João Branco esclarece, a sua chancelaria preocupou-se "em promover uma concepção de reino e de espaço de domínio territorial do rei" ${ }^{50}$, factor de ligação de gentes e corpos sociais distintos, caminho, afinal, de constituição da nação.

Ainda infante, D. Sancho casou com Dulce de Aragão, numa aliança bem diferente daquela que terá unido sua irmã Mafalda a Raimundo de Barcelona. Dessa união proveio numerosa e ilustre prole, a que já chamámos a primeira geração europeia de infantes de Portugal ${ }^{51}$.

Falecido no final de Março de 1211, D. Sancho I escolheu (e achou) sepultura no mosteiro de Santa Cruz de Coimbra, junto de seus pais, de sua esposa e de alguns dos seus filhos.

\section{Conclusão}

Mafalda de Mouriana, como ficou lembrada nos documentos de seu marido, o rei D. Afonso Henriques, rainha de Portugal durante treze anos, não deixou memórias notáveis no reino a que veio para reinar. Ela é, assim, uma personagem fugidia na história de Portugal. A sua breve vida como rainha, aliada a ter sido vivida em tempo de guerreiros, não permitiu que a sua imagem se impusesse, se é que a sua personalidade assim o indicava. Por isso, é muito pouco aquilo que, de objectivo, nos permitem os docu-

\footnotetext{
50 2005, p. 171.

512007.
} 
mentos de seu marido e de seus descendentes, ou aquilo de que a tradição se faz eco acerca desta rainha, esposa do rei Fundador.

A memória de D. Mafalda é escassa, vaga, incerta. Feita do trivial da vida de uma mulher, no casamento e na ligação aos filhos, alguns actos, poucos e banais, ligados à piedade do seu tempo e às possibilidades da sua condição constituíram e adornaram a sua lembrança. Por isso, em breve, ela ficou esquecida, obliterada entre os seus próprios descendentes, primeiro passo para o esquecimento de uma nação que o tempo permitiu ir ganhando séculos e outras lembranças. De resto, aquilo que Mafalda de Mouriana e Sabóia teve de fazer, como a adaptação a um novo meio humano e social, a forma como acompanhou e viveu os problemas de seu marido, nas relações com o reino vizinho e com a Santa Sé, o papel que teve (se o teve) na protecção a correntes monásticas novas, como os cistercienses, se o fez ou como o fez, tudo isto nos fica no mais perfeito desconhecimento.

\section{Fontes e estudos}

\section{SIGLAS:}

CCR = Crónica dos Cónegos Regrantes de Santo Agostinho.

$\mathrm{DR}=$ Documentos medievais portugueses: documentos régios. Vol. 1/I. Documentos dos Condes Portucalenses e de D. Afonso Henriques. A D. 1095-1185

$\mathrm{LF}=$ Liber fidei Sanctae Bracarensis ecclesiae.

$\mathrm{LK}=$ Liber anniversariorum ecclesiae cathedralis colimbriensis (Livro das Kalendas).

LLCDP $=$ Livro de linhagens do Conde D. Pedro. Vid. Livros de linhagens.

$\mathrm{LV}=$ Livro velho de linhagens. Vid. Livros de linhgens.

PMH. Inquisitiones = Portugaliae monumenta historica a saeculo octavo post Christum usque ad quintum decimum. Inquisitiones.

PMH. Leges = Portugaliae monumenta historica a saeculo octavo post Christum usque ad quintum decimum. Leges.

PMH. Scriptores = Portugaliae monumenta historica a saeculo octavo post Christum usque ad quintum decimum / iussu Academiae Scientiarum Olisiponensis edita. 1: Scriptores.

\section{Fontes impressas}

Anais, crónicas e memórias avulsas de Santa Cruz de Coimbra. Textos publicados com uma introdução por António Cruz. Porto: Biblioteca Pública Municipal do Porto, 1968. 
Annales Domni Alfonsi Portugallensium Regis: vid. BLÖCKER-WALTER, Monica - Alfons I von Portugal.

"Annales Portugalenses Veteres». Estudo e edição por Pierre David. Revista Portuguesa de História. Coimbra. 3 (1947) 81-128 (também publicado in IDEM - Études historiques sur la Galice et le Portugal du VIe au XII siècle. [S.1.: s.n.], 1947, p. 257-340).

BRANDÃO, António, O. Cist. (1584-1637) - Monarquia Lusitana. III Parte: Que contem a historia de Portugal desde o conde D. Henrique, até todo o reinado del Rey Dom Afonso Henriques [...]. IV Parte: Que contem a historia de Portugal desde o tempo delRey Dom Sancho Primeiro, até todo o reinado delRei D. Afonso III [...]. Lisboa: no Mosteiro de S. Bento, por Pedro Craesbeck, 1632. Reed. Fac-similada, com introdução e notas de A. Dias Farinha e Eduardo dos Santos. Lisboa: Imprensa Nacional - Casa da Moeda, 1974.

Chancelarias Portuguesas. D. Pedro I. Edição preparada por A. H. de Oliveira Marques. Lisboa: Instituto Nacional de Investigação Científica - Centro de Estudos Históricos. Faculdade de Ciências Sociais e Humanas, 1984.

Chronica Gothorum, vid. Portugaliae monumenta historica: Scriptores.

Crónica de Portugal de 1419. Edição crítica com introdução e notas por Adelino de Almeida Calado. Aveiro: Universidade de Aveiro, Fundação João Jacinto de Magalhães, 1998.

Crónica Geral de Espanha de 1344. Edição crítica do texto português por Luís Filipe Lindley Cintra. 4 vols.. Lisboa: Academia Portuguesa da História, 1951-1990.

Crónicas breves e memórias avulsas de S. Cruz de Coimbra. Edições fac-similada, paleográfica e crítica, com anotações por Fernando Venâncio Peixoto da Fonseca. Lisboa: [s.n.], 2000.

Documentación (La) pontificia hasta Inocencio III (965-1216). Edição por Demetrio Mansilla. Roma: Instituto Español de Estudios Eclesiásticos, 1955.

Documentos medievais portugueses: documentos régios. Vol. 1/I. Documentos dos Condes Portucalenses e de D. Afonso Henriques. A D. 1095-1185. Vol. 2/II: Aditamentos, fontes e índices. Edição por Rui Pinto de Azevedo. Lisboa: Academia Portuguesa da História, 1958-1962.

Documentos medievales del Reino de Galicia: Fernando II. Edição por Manuel Recuero Astray [et al.]. Ferrol: Xunta de Galicia, 2000.

Expugnatione (De) Lyxbonensi, vid. Conquista de Lisboa aos Mouros: Relato de um Cruzado.

FERNANDES, Rui - Descrição do terreno ao redor de Lamego duas léguas. Ed. Amândio Morais Barros. S.l. Edições Afrontamento, 2001.

Hagiografia de Santa Cruz de Coimbra: Vida de D. Telo, Vida de D. Teotónio, Vida de Martinho de Soure. Edição crítica por Aires A. Nascimento. Lisboa: Edições Colibri, 1998.

Liber anniversariorum ecclesiae cathedralis colimbriensis (Livro das Kalendas). 2 vols.. Edição crítica por Pierre David e Torquato de Sousa Soares. Coimbra: Universidade de Coimbra, 1947-1948.

Liber fidei sanctae bracarensis ecclesiae. Edição crítica por Avelino de Jesus da Costa. 3 vols.. Braga: Junta Distrital de Braga, 1965-1990.

Livro Santo de Santa Cruz: cartulário do séc. XII. Edição por Leontina Ventura e Ana Santiago de Faria. Abertura de Salvador Dias Arnaut. Coimbra: Instituto Nacional de Investigação Científica, 1990.

Livros de linhagens: Livro Velho de Linhagens; Livro de Linhagens do Deão; Livro de Linhagens do Conde D. Pedro, vid. Portugaliae monumenta historica [...]. Nova série.

PETRUS VENERABILIS, abbas cluniacensis († 1156) - "Epistolarum libri sex». In Patrologia latina, cursus completus [...]. Edita J.-P. Migne. Paris, 1890, vol. CLXXXIX, col. 61-486.

Portugaliae monumenta historica a saeculo octavo post Christum usque ad quintum decimum / iussu Academiae Scientiarum Olisiponensis edita. 1: Scriptores. 3: Leges et consuetudines. 
4: Inquisitiones. Edição por Alexandre Herculano [continuada, na série Inquisitiones, por J. S. Mendes Leal [et al.]. Lisboa: Academia das Ciências, 1856-1961. (reimpr., 1967).

Portugaliae monumenta historica a saeculo octavo post Christum usque ad quintumdecimum / iussu Academiae Scientiarum Olisiponensis edita. Nova série. 1: Livros velhos de linhagens. Edição crítica por Joseph Piel e José Mattoso. 2/I-II: Livro de Linhagens do conde D. Pedro. Edição crítica por José Mattoso. Lisboa: Academia das Ciências de Lisboa, 1980.

Recueil des chartes de l'abbaye de Clairvaux au XIIe siècle. Edição por Laurent Veyssière. Paris: Éditions du Comité des Travaux historiques et scientifiques, 2004.

Regesta de Fernando II. Estudo, com edição e sumários por Julio González. 2 vols. Madrid: Consejo Superior de Investigaciones Científicas, Instituto Jerónimo Zurita, 1943.

REIS, Balthasar dos (séc. XvII) - Breve relação da fundação e antiguidade do Mosteiro de Santa Maria da Salzeda. Lisboa: Biblioteca Nacional, 1936.

Relato da conquista de Santarém, vid. Portugaliae monumenta bistórica: Scriptores; vid. também NASCIMENTO, Aires A. - O júbilo da vitória.

SANTA MARIA, Nicolau de - Crónica dos cónegos regrantes do patriarca Santo Agostinho. 2 vols., Lisboa: Of. de João da Costa, 1668.

SOUSA, António Caetano de, C.R. (1735-1749) - História genealógica da Casa Real portuguesa. 14 vols.. Lisboa Occidental: na Of. De Joseph Antonio da Silva; na Of. Silviana, 1735-1749. Provas. 6 vols.. Lisboa: na Of. Silviana da Academia Real, 1739-1748. (2. ${ }^{a}$ ed., Coimbra: Livraria Atlântida, Editora, 1946-1954).

Vita Martini Sauriensis, vid. Hagiografia de Santa Cruz de Coimbra.

Vita Theotonii, vid. Hagiografia de Santa Cruz de Coimbra.

\section{Estudos}

AMADO, Teresa, 2003, "Ainda sobre o milagre de Ourique». In MORAIS, Ana Paiva; ARAÚJO, Teresa; PAIXÃO, Rosário Santana, coord. - Da decifração em textos medievais / IV Colóquio da Secção Portuguesa da Associação Hispânica de Literatura Medieval. Lisboa: Edições Colibri, p. 301-310.

AMARAL, Diogo Freitas do, 1996, «Em que momento se tornou Portugal um País independente». In 2. ${ }^{\circ}$ Congresso Histórico de Guimarães: actas. [Guimarães]: Câmara Municipal de Guimarães; Universidade do Minho, vol. 2, p. 139-181.

ARIÉS, Philippe; DUBY, Georges (dir.), 1990, História da vida privada. Tradução portuguesa, com revisão científica de Armando Luís de Carvalho Homem. Vol. 2: Da Europa feudal ao Renascimento. Lisboa: Edições Afrontamento.

AZEvedo, Luís Gonzaga de, 1942, História de Portugal. Prefácio e revisão de Domingos Maurício Gomes dos Santos. Vol. 4. Lisboa: Edições "Bíblion».

AZEVEDO, Rui Pinto de, 1943, "Ainda sôbre a data em que Afonso Henriques tomou o título de rei». Revista Portuguesa de História. Coimbra. 1, 177-183, 8 est. .

, 1957, "A carta ou memória do cruzado inglês R. para Osberto de Bawdsey, sobre a conquista de Lisboa em 1147». Revista Portuguesa de História. Coimbra. 7, 343-370.

BARBOSA, Pedro Gomes, 1991, Documentos, lugares e homens: estudos de história medieval. Lisboa: Edições Cosmos. 
1991, “São Bernardo e a independência de Portugal». In IX Centenário do Nascimento de S. Bernardo: Encontros de Alcobaça e Simpósio de Lisboa: actas. Braga: Faculdade de Teologia, Universidade Católica Portuguesa; Câmara Municipal de Alcobaça, p. 337-349.

2004, Conquista de Lisboa: 1147: a cidade reconquistada aos Mouros. Lisboa: Tribuna da História.

BARROCA, Mário Jorge, 2000, Epigrafia medieval portuguesa: 862-1422. 3 vols. (em 4 tomos). Lisboa: Fundação Calouste Gulbenkian; Fundação para a Ciência e a Tecnologia.

BAUBETA, Patricia Anne Odber de,1988, "Some Early English Sources of Portuguese History». Estudos Medievais. Porto. 9, 201-210.

BEIRANTE, Maria Ângela Rocha, 1996, "D. Afonso Henriques e as cidades". In 2. ${ }^{\circ}$ Congresso Histórico de Guimarães: actas. [Guimarães]: Câmara Municipal de Guimarães; Universidade do Minho, vol. 5, p. 223-233.

BENEVIDES, Francisco Fonseca, 1878, Rainhas de Portugal: estudo bistórico com muitos documentos. Vol. 1. Lisboa: Typ. Castro Irmão.

BENNETT, Matthew, 2001, "Military Aspects of the Conquest of Lisbon, 1147». In PHILLIPS, Jonathan; HOCH, Martin, ed. - The Second Crusade: Scope and Consequenses. Manchester: Manchester University Press, p. 71-89.

BISHKO, Charles J., 1980, Studies in Medieval Spanish Frontier History. London: Variorum Reprints. 1984, Spanish and Portuguese Monastic History, 600-1300. London: Variorum Reprints.

BLÖCKER-WALTER, Monica, 1966, Alfons I von Portugal: Studien zu Geschichte und Sage des Begründers der Portugiesischen Unabhängigkeiten. Zurique: Fretz und Wasmuth Verlag.

BRANCO, Maria João Violante, 1993, "Portugal no reino de León: etapas de uma relação (866-1179)". In El reino de León en la Alta Edad Media. Vol. 4: La monarquía (1109-1230). León: Centro de Estudios e Investigación "San Isidoro», p. 533-625.

1996, "A conquista de Lisboa revisitada: estratégias de ocupação do espaço político, físico e simbólico». In 2. ${ }^{\circ}$ Congresso Histórico de Guimarães: actas. [Guimarães]: Câmara Municipal de Guimarães; Universidade do Minho, vol. 2, p. 119-137.

2001, "Introdução: a conquista de Lisboa na estratégia de um poder que se consolida". In NASCIMENTO, Aires A., ed. - A conquista de Lisboa aos Mouros: relato de um cruzado. Lisboa: Vega, p. 9-51.

2005, D. Sancho I: o filbo do fundador. [Lisboa]: Círculo de Leitores.

CASTRO, José Ariel, 1992, "Afonso de Portugal, 11. ${ }^{\circ}$ grão-mestre da Ordem do Hospital de S. João de Jerusalém». In IX Congresso da Associação Internacional de Lusitanistas: actas. Coimbra, p. 819-857.

COELHO, Maria Helena da Cruz, 1955, Superstição, fé e milagres na Idade Média. Coimbra: Inatel, Delegação de Coimbra.

CORDEIRO, Luciano, 1984, Portuguezes fóra de Portugal: Berengella e Leonor, rainhas da Dinamarca. Lisboa: Imprensa Nacional [reimpr., com introdução de José Mattoso]. 1899, A Condessa Mahaut. Lisboa: A Liberal.

CORTE-REAL, Manuel, 1977, "As alianças matrimoniais dos filhos de D. Afonso Henriques na política externa portuguesa». In 2. ${ }^{\circ}$ Congresso bistórico de Guimarães: actas. [Guimarães]: Câmara Municipal de Guimarães; Universidade do Minho, vol. 2., p. 447-455.

COSTA, Avelino de Jesus da, 1948, "A Ordem de Cluny em Portugal». Cenáculo. Braga. 3, $186-220$.

1983, "A biblioteca e o tesouro da Sé de Coimbra nos séculos XI a XVI». Boletim da Biblioteca da Universidade. Coimbra. 38, 1-226. 
1984, "D. João Peculiar co-fundador do mosteiro de Santa Cruz de Coimbra, bispo do Porto e arcebispo de Braga». In Santa Cruz de Coimbra do século XI ao século XX: estudos. Coimbra: Comissão Executiva do IX Centenário do Nascimento de S. Teotónio, p. $59-83$.

1992, Estudos de cronologia, diplomática, paleografia e bistórico-linguísticos. Porto: Sociedade Portuguesa de Estudos Medievais.

, 1994, «S. Teotónio, primeiro prior do mosteiro de S. ${ }^{\text {ta }}$ Cruz de Coimbra, glória das dioceses de Coimbra, de Viana do Castelo e de Viseu». In III Colóquio Galaico-Minboto: actas. Viana do Castelo: Câmara Municipal de Viana do Castelo, vol. 1, p. 29-49.

CRUZ, António, 1984, «D. Teotónio, prior de Santa Cruz, o primeiro cruzado e o primeiro santo de Portugal». In Santa Cruz de Coimbra do século XI ao século XX: estudos. Coimbra: Comissão Executiva do IX Centenário do Nascimento de S. Teotónio, p. 21-58.

CUNHA, Armando Santinho; FERREIRA, F. E. Rodrigues, 1998, Vida e morte na época de D. Afonso Henriques. Lisboa: Hugin Editores, Lda.

DAVID, Pierre, 1947, Études historiques sur la Galice et le Portugal du VIe au XIIe siècle. Lisboa; Paris: [s.n.].

Dicionário de história de Portugal, vid. SERRÃO, Joel, dir.

Dicionário ilustrado da história de Portugal, vid. PEREIRA, José Costa; MARTINS, José Frederico Ferreira, ed. lit.

Dicionário da literatura medieval galega e portuguesa, vid. LANCIANI, Giulia; TAVANI, Giuseppe, coord.

Dictionaire Historique de la Papauté, vid. LEVILLAIN, Philippe, dir.

DUBY, Georges, 1973, Le dimanche de Bouvines: 27 Juillet 1214. Paris: Gallimard.

EDGINGTON, Susanne B., 1996, "The Lisbon Letter of the Second Crusade». Historical Research. 69, 328-339.

2001, "Albert of Aachen, St Bernard and the Second Crusade». In PHILLIPS, Jonathan; HOCH, Martin, ed. - The Second Crusade: Scope and Consequenses. Manchester: Manchester University Press, p. 54-70.

ERDMANN, Carl, 1935, o Papado e Portugal no primeiro século da história portuguesa. Coimbra: Coimbra Editora, (reed. fac-similada, Braga: Comissão Executiva do 2. ${ }^{\circ}$ Congresso Histórico de Guimarães, 1996).

1940, De como D. Afonso Henriques assumiu o título de Rei. Coimbra: Instituto Alemão da Universidade de Coimbra.

FERNANDES, A. de Almeida, (1985) Os primeiros documentos de Santa Maria da Salzeda (Até à morte da fundadoura). Comentários e defesa. Guimarães: Sociedade Martins Sacramento.

FERNÁNDEZ RODRÍGUEZ, Manuel, 2004, Toronium. Aproximación a la historia de una tierra medieval. Instituto de Estudios Gallegos "Padre Sarmiento", Santiago de Compostela.

FIGANIÈRE, Frederico Francisco de la, 1859, Memórias das rainhas de Portugal (D. Theresa Santa Isabel). Lisboa: Typographia Universal.

FOREY, Alan J., 2004, "The Siege of Lisbon and the Second Crusade». Portuguese Studies. London. 20, 1-13.

GOFFIN, Louis, 1967, Fernand de Portugal comte de Flandre et de Hainaut. Lisboa: Academia das Ciências de Lisboa.

GOMES, Saul António, 1996, "Os panteões régios monásticos portugueses nos séculos Xil e XII»" In 2. ${ }^{\circ}$ Congresso Histórico de Guimarães: actas. [Guimarães]: Câmara Municipal de Guimarães; Universidade do Minho, vol. 4, p. 281-295. 
HERCUlANO, Alexandre, 1980-1981, História de Portugal desde o começo da monarquia até o fim do reinado de Afonso III. Prefácio e notas críticas de José Mattoso. 4 vols. Lisboa: Livraria Bertrand.

HIESTAND, Rudolf, 2001, "The Papacy and the Second Crusade». In PHILLIPS, Jonathan; HOCH, Martin, ed. - The Second Crusade: Scope and Consequenses. Manchester: Manchester University Press, p. 32-53.

KOSTO, Adam J., 2001, "The Liber feudorum maior of the Counts of Barcelona: The Cartulary as an Expression of Power" Journal of Medieval History. 27, 1-22.

KRUS, Luís, 1994, Passado, memória e poder na sociedade medieval portuguesa: estudos. Redondo: Patrimonia.

LANCIANI, Giulia; TAVANI, Giuseppe (coord.), 1993, Dicionário da literatura medieval galega e portuguesa. Lisboa: Editorial Caminho.

LECLERCQ, Jean, 1971, "L'encyclique de Saint Bernard en faveur de la croisade». Revue Bénédictine. 81, 282-308.

LEVILlain, Philippe (dir.), 1994, Dictionnaire historique de la Papauté. Paris: Arthème Fayard.

LINEHAN, Peter, 1996, “Utrum reges Portugalie coronabantur annon». In 2. ${ }^{\circ}$ Congresso histórico de Guimarães: actas. [Guimarães]: Câmara Municipal de Guimarães; Universidade do Minho, vol. 2, p. 387- 401.

LIVERMORE, Harold, 1990, "The "Conquest of Lisbon" and its Autor». Portuguese Studies. London. 6, 1-16.

LOBO, António Ilídio Lima Leite, 1998, «D. Mafalda de Mouriana/Sabóia, mulher de D. Afonso Henriques». Armas \& Troféus. Lisboa. VIII série. 2, 139-158.

LOMAX, Derek W., 1964, "Los "Magni rotuli pipae” y el medievo hispánico». Anuario de Estudios Medievales. Barcelona. 1, 543-548.

MARQUeS, A. H. de Oliveira; DIAS, João José Alves [et al.], 2003, Atlas histórico de Portugal e do Ultramar Português. [Lisboa]: Centro de Estudos Históricos, 2003.

; GONÇALVES, Iria; ANDRADE, Amélia Aguiar, ed. lit., 1990, Atlas de cidades medievais portuguesas: séculos XII-XV. Lisboa: Centro de Estudos Históricos da Universidade Nova de Lisboa.

MARQUES, José, 1990, "A realidade da igreja no tempo de S. Teotónio». Revista da Faculdade de Letras: História. Porto. II série. 7, 9-34.

, 1996, "As doações dos condes portucalenses e de D. Afonso Henriques à Igreja». In 2. ${ }^{\circ}$ Congresso Histórico de Guimarães: actas. [Guimarães]: Câmara Municipal de Guimarães; Universidade do Minho, vol. 5, p. 325-349.

MARQUES, Maria Alegria Fernandes, 1998, Estudos sobre a Ordem de Cister em Portugal. Lisboa: Edições Colibri; Faculdade de Letras da Universidade de Coimbra.

2007, "A primeira geração europeia de infantes de Portugal. Os filhos de D. Sancho I", in X Congresso das Academias Ibero-Americanas da História. Ibero-América. Convergências e Reptos: Justiça, Propriedade, Instituições, Liberdade e Segurança. Actas. 2 a 5 Novembro de 2006. Lisboa: Academia Portuguesa da História, 2007, 295-318.

2011, D. Dulce. Rainha Fecunda. Matosinhos: Quid Novi.

, D. Matlide, D. Teresa, D. Mafalda, D. Sancha. As primeiras infantas de Portugal. Matosinhos: Quid Novi.

; SOAlheiro, João, 2008, A corte dos primeiros reis de Portugal. D. Afonso Henriques. D. Sancho I. D. Afonso II. Gijón: Editorial Trea.

MARTINS, Armando Alberto, 2003, O Mosteiro de Santa Cruz de Coimbra na Idade Média. Lisboa: Centro de História da Universidade de Lisboa. 
MATTOSO, José, 2006, D. Afonso Henriques. [Lisboa]: Círculo de Leitores.

MAURÍCIO, Carlos C., 1989, "Na manhã fértil: sondando o Milagre de Ourique na cultura portuguesa». Ler História. Lisboa. 18, 3-28.

, 1990, "Entre silêncio e ouro: sondando o milagre de Ourique na cultura portuguesa". Ler História. Lisboa. 20, 3-37.

MONTEIRO, J. P. Franco, 1893, As donatárias d'Alenquer: historia das rainhas de Portugal e da sua casa e estado. Lisboa: M. Gomes Editor.

NASCIMENTO, Aires A., 1978, "O milagre de Ourique num texto latino-medieval de 1416". Revista da Faculdade de Letras de Lisboa, 265-274.

2005, "O júbilo da vitória: celebração da tomada de Santarém aos mouros (A. D. 1147" estudo, edição do texto latino e tradução portuguesa). In X Congrés Interuniversitari de Filologia Valenciana, vol. 3, p. 1217-1232.

O'CALLAGHAN, Joseph Francis, 2003, Reconquest and Crusade in Medieval Spain. Philadelphie: University of Pennsylvania Press.

Oliva, Gianni, 1998, I Savoia. Novecento anni di una dinastia. Milano: Mondadori.

OliveIRA, Miguel de, 1945, Ourique em Espanha. Lisboa: Pro Domo.

PEREIRA, Armando de Sousa, 1996, "A conquista de Santarém na tradição historiográfica portuguesa». In 2. ${ }^{\circ}$ Congresso Histórico de Guimarães: actas. [Guimarães]: Câmara Municipal de Guimarães; Universidade do Minho, vol. 5, p. 297-323.

PEREIRA, José Costa; MARTINS, José Frederico Ferreira, ed. lit., 1986, Dicionário ilustrado da história de Portugal. Vols. 1 e 2. Lisboa: Alfa.

PHILLIPS, Jonathan, 1997, "St. Bernard of Clairvaux, the Low Countries and the Lisbon Letter of the Second Crusade». Journal of Ecclesiastical History. 48, 485-497.

2000, "Ideas of Crusade and Holy War in De Expugnatione Lyxbonensi (The Conquest of Lisbon)». Studies in Church History. 36, 123-141.

2001, "Papacy, Empire and the Second Crusade». In IDEM; HOCH, Martin, ed. - The Second Crusade: Scope and Consequenses. Manchester: Manchester University Press, p. 15-31.

PICOITO, Pedro, 2006, "O cavaleiro, a mulher e o rei. Uma assuada no século XII", in O corpo e o gesto na civilização medieval. Actas do Encontro (11-13 de Novembro de 2003), Lisboa, Edições Colibri, p. 247-262.

PIMENTEL, António Filipe, 2005, A morada da Sabedoria, vol. I: O paço real de Coimbra: das origens ao estabelecimento da Universidade, Coimbra: Almedina.

RECUERO ASTRAY, Manuel, 1996, "Consideraciones sobre la situación histórica de la Península Ibérica en el siglo XII». In 2. ${ }^{\circ}$ Congresso Histórico de Guimarães: actas. [Guimarães]: Câmara Municipal de Guimarães; Universidade do Minho, vol. 2, p. 25-37.

REGLERO DE LA FUENTE, CARLOS M., 2007, Cluny en España. Los prioratos de la província y sus redes sociales (1073-ca. 1270). León: Centro de Estudios e Investigación "San Isidoro".

REILly, Bernard F., 1998, The Kingdom of León-Castilla under King Alfonso VII, 1126-1157. Philadelphia: University of Philadelphia Press. CRONOS

RIBEIRO, João Pedro, 1810, Dissertações chronológicas e críticas sobre a bistória e jurisprudência ecclesiástica e civil em Portugal. Vol. 1. Lisboa: Academia das Ciências.

RODRIGUES, Ana Maria S. A., 1996, "Em busca de D. Afonso Henriques através de oito séculos de historiografia portuguesa”. In 2. ${ }^{\circ}$ Congresso Histórico de Guimarães: actas. [Guimarães]: Câmara Municipal de Guimarães; Universidade do Minho, vol. 3, p. 5-19.

SANTARÉM, Visconde de, 1865, Quadro elementar das relações políticas e diplomáticas de Portugal com as diversas potências do Mundo desde o princípio da monarquia portuguesa até aos nossos dias. 14 vols. Lisboa: Academia Real das Ciências. 
SÃO PAYO, Luiz de Mello Vaz de, 2002, A herança genética de D. Afonso Henriques. Porto, Centro de Estudos de História da Família da Universidade Moderna do Porto.

SARAIVA, J. Mendes da Cunha, 1928, "A campanha de Ourique». Nação Portuguesa. Lisboa. V série. 1, 417-420.

SERRÃO, Joel, dir., 1983-2000, Dicionário de história de Portugal. Continuado por António Barreto e Maria Filomena Mónica, ed. lit. 9 vols. Porto: Figueirinhas, (1. ${ }^{a}$ ed., 4 vols.. Lisboa: Iniciativas Editoriais, [1971]).

; MARQues, A. H. de Oliveira (dir.), 1993-1996, Nova História de Portugal. Vol. 3: Portugal em definição de fronteiras: do condado portucalense à crise do século XIV. Lisboa: Editorial Presença.

SILVA, Manuela Santos, 1996, "Alguns passos da acção do conquistador na Estremadura litoral". In 2. ${ }^{\circ}$ Congresso Histórico de Guimarães: actas. [Guimarães]: Câmara Municipal de Guimarães; Universidade do Minho, vol. 2, p. 109-116.

SOALHEIRO, João, 2008, VER: Marques, Maria Alegria Fernandes.

SOARES, Torquato de Sousa, 1974, «D. Afonso Henriques». In CIDADE, Hernâni (dir.), Os grandes portugueses. Lisboa: Arcádia, vol. 1, p. 23-42.

SOUSA, Bernardo de Vasconcelos e, 1996, "D. Afonso Henriques nas primeiras crónicas portuguesas». In $2 .{ }^{\circ}$ Congresso Histórico de Guimarães: actas. [Guimarães]: Câmara Municipal de Guimarães; Universidade do Minho, vol. 3, p. 21-31.

UBIETO ARTETA, A., 1963, "Relaciones de Aragón y Portugal durante el siglo XI». Bracara Augusta. 14-15, 29-40.

VEIGA, Augusto Botelho da Costa, 1939, Estudos de história militar portuguesa. II: Análise da tradição e da polémica de Ourique. Lisboa: Typ. Henrique Torres.

, 1940, "Ourique - Vale de Vez». Anais: ciclo da fundação da nacionalidade. Lisboa: Academia Portuguesa da História, vol. 1, p. 9-186.

VERDON, Jean, 1999, La femme au Moyen Age. Paris: Editions Gisserot.

WARREN, W. L., 2000, Henry II. London: New Haven.

WILLIAMS, John Bryan, 1996, "The Making of a Crusade: the Genoese Anti-Muslim Attacks in Spain, 1146-1148». Journal of Medieval History. 23, 29-53. 